\title{
TA, relationship with one's own learning process and strategic studying
}

\section{(C) 2012 Cesare Fregola}

\begin{abstract}
Life-long learning is an increasingly relevant need of our time. Educational perspectives currently tend to focus beside the single subjects (Foreign Languages, Maths, History) - on how, while learning, you can learn to learn. Considering this perspective, we have been integrating Transactional Analysis in the training for future Primary School Teachers. Our objectives are both more traditional applications intended to improve the relationship between teachers and teachers, teachers and families, and to observe, study and intervene in the relationship which children create with their learning process. The writing on emotional drivers, which we presented on IJTAR - International Journal of TA Research-for didactics of Mathematics, has proved very helpful for other subjects and in learning how to learn.
\end{abstract}

Our experimentation involved 10 classes of a primary school, and enabled us to create several tools (interviews to identify drivers, egogram interview, check lists for the observation of transactions during the lessons). The learning outcomes have been analysed by the teachers according to some against indicators of learning and didactic objectives established within a systematic frame of reference. This model for didactics in TA clearly contributes to the construction of a learning environment, enhancing both the expression of the Free Child and Self-efficacy.

\section{Introduction}

I am, we are, honoured to be here today with you, and to have a chance to talk about some research we have carried out in Italy with future teachers of Primary School. Primary School is attended by children between 3 and 11, and their teachers have to attend a five- year Graduate Course at University, in the Department of Science of Primary School Teaching. Students, besides taking exams on the subjects in the curriculum, have to do an apprenticeship in schools. They take part in activities in class with the children and their teachers. In order to receive a qualification for teaching, they have to write a final essay, divided in three parts:

- A project of observation of the interaction among children and between children and teachers

- A didactic project which they have to carry out in the class

- A personal project about their own competences in their future role of teachers

Ferdinando Montuschi, a TSTA in the Educational Field, as some of you may know, was Head of the Department until a few years ago, and some of his lessons focused on some basic TA themes. In that period, working in the Department of General Didactics and Experimental Pedagogy run by Professor Daniela Olmetti Peja, I had the chance to follow some students who were writing their final essay. Inspired by TA, I then started conducting my first researches. To my great joy, research on Emotional Drivers and their influence on the learning process of Mathematics was published in number 1 of IJTAR.

Further experimentations have been carried out which haven't been published yet as they are still being validated:

- Drivers in learning a foreign language

- Drivers in learning grammar and history

- First observations on intuition in Maths and the Little Professor

- Teacher's relational competences and the learning outcomes for reading based on the creation of a Stroke Bank of the Class

Currently, a validated study is: Influence of Emotional Drivers in the development of learning strategies and managing examination anxiety. This study led to a model of integration of Self-efficacy and Permissions for managing Drivers (Fregola C., Olmetti Peja D., 2010).

Three other studies are being completed, and the issues we are exploring are: 
- Changes in the Cultural parent due to social, economic and intercultural innovations and to Web 2.0, which developed depending on technological evolution and globalisation process. One study in particular concerns the learning processes involved in a functional use of videogames. Another, the profile of parenthood expected by children starting from their perceptions and experience as "native digitals" (Prensky M., 2009, 2001; Ferri P., 2011; Jenkis H., 2010).sons and daughters.

- Changes in Ego States related to watching a film in class, the egogram of children and profiles of creativity according to assessment fantasia, a valid principle which validates the idea that one's creativity can be educated; children's egogram and the learning outcomes in reading, or in making a perceptive model of the globe

- Observation of the Discount Matrix in a model of simulation games (in this context, the term simulation games has a pedagogical connotation. It refers to a game used in a class with 9-year-old children. The game was projected and created to enhance group problem-solving with three main objectives: to have children understand and learn the concept of Isometry of Geometry, to improve Social and School self-efficacy and to improve mnemonic retention a long time after the lesson. (Fregola C., \& Piu A., 2010, 2011). This research is lead along with Angela Piu of the Aosta University)

The idea of this paper developed, together with Adele, during the meetings of TA MSc in the Educational Field, in the PerFormat office in Rome. Performat is a PostGraduate School in Transactional Analysis Psychotherapy formally recognised by the Ministry of Education and Research. It is also a training agency composed of psychologists, doctors, qualified professionals in the area of training and business consultancy who deal with the promotion of healthculture and communication in interpersonal relationships, working places, in the area of training and healing places, in the educational processes.

\section{The quest for a path to follow in a learning-teaching process which enhances learning how to learn in the context of complexity}

The considerations in this paper are related to different disciplines. It describes a first embryonic stage of a model for Didactics and Experimental Pedagogy empowered by the contribution from TA, as well as a possible integration of it in the system of competences of future teachers. The need for a frame of reference for teaching didactics has long been experienced by people who work in educational and training contexts.

The reflections we are going to share originate from the different researches described above and, above all, from the methodology that is being followed to carry out such researches. A fortunate circumstance, in this, is that the target students already are digital natives themselves (Mark Prensky) who interact with real children and expert teachers, in a place, the University of Roma Tre, where providing training for the students' professional future is one of the main objectives.

\section{Why did we introduce the term Strategic student?}

In the last century the "store-houses" of knowledge, knowing how to be and do, were filled during the first years of life. Then, the supplies stocked up in there would be enough for one's entire life.

Indeed, the elements stocked up have later evolved, grown and deepened and finally shaped themselves in accordance with one's specialisations. A current tendency is to think that nowadays there is no point in stocking up store-houses with decaying materials, contents and information which may change with time, be replaced or continuously updated. Thus, the main need of basic training currently consists in providing people with minimal knowledge, basic fundamental competencies, necessary in order for social communication to be effective in different roles in different situations of life. Therefore, when stocking supplies, the goods one chooses must be dynamic, thus enabling one to learn to build one's knowledge, to define knowledge and learn to build processes which continuously create a bond between know, know how to do and to be in a dimension where one learns to belong in society and know how to become a person in the context of complexity. Our research was based on this assumption, and it mainly focused on strategic students, who represent a metaphor of competencies required for life long learning in a society that has been defined Society of knowledge. It also focused on strategic teachers who, in accordance with such a perspective, learn how to provide structure, shape and content in contexts of training and basic education. Strategic student, thus, is a social role inhabited by the trainees in order to lay the foundations for their identity and sense of belonging in the society of knowledge.

The society of knowledge, or of learning, can be considered an image that well describes and evokes the new human condition, a condition which has been and is being determined (Alberici A., 2002). This new or renewed condition can be related to three dimensions:

- Information and communication (TIC), in particular the Net. It gave rise to a kind of social communication through real and virtual interconnection (from Facebook to twitter, from email to Internet portals...) which affected places and manners of personal interaction and economic processes;

- Social and individual development in a global village as defined by Marshall McLuhan in which men and women work, live and organise their existences; these people, everyday, meet and clash with a new capital of knowledge and multi-ethnic and intercultural interactions.

- The relationship of a person with one's own learning process which can be intended like a connection, a bond established between the 
individual, the development of one 's own storehouse of learning how to learn during the cycle of life (Erikson, E. H., 1999). All this is related to the roles one is going to play and inhabit (Napper R., 2011) while making a contract which is explicitly and implicitly determined with the net of relationships one belongs to either directly or indirectly and in relation to the development of the environment, context and situations.

Lifelong learning, thus, marks the passing from knowledge helpful for one's entire life to knowledge helpful to learn for one's entire life, so that unstable behaviours can be related to three principles:

- A conception of human development characterised by dynamic processes within the poles continuitydiscontinuity

- A conception of development which is generally used to indicate a process with a beginning and an end during the age of development and which goes beyond and pervades the other phases of life as well

- A conception of change which contrasts with development as means of interpretation of continuous possibility to change in every phase of human life. Accordingly, it defines both complexity and the plastic dimension of adult life in the continuum of existence.

Adult age does not therefore represent a conclusive phase of evolutional development, but one of the phases of a continuous process (Romanini M.T., 1999).

\section{TA and learning relationship}

The Educational Field of TA can give relevant contribution, as it can provide support for the generation of contextual and situational knowledge knowledge of here and now, by which is meant social and cultural current moment. This is possible if we obtain the required knowledge from the external world and turn it into knowledge which can be defined dynamic knowledge due to its interaction with the inner world, with the frame of reference (Miglionico 2000).

Such interaction leads to integrating tradition and innovation, related to the neo-psyche in action (Novellino M., 2012), personal history and experience, and growth, thus enhancing a reinterpretation of identity in a renewed multicultural perspective. In the TA community, "education and/or growth of personality as well as development within the social frame of reference" is the objective of the educational field (EATA). We accordingly intend to contribute to applying EATA guidelines in our work.

In the educational field new perspectives on how people learn and on how education and training can be more effective are proposed; we have new intuitions on educational approaches, including experiential learning, student-centred education, self-directed learning and learning styles; different styles to follow when things go wrong or are blocked; a fear-free theory which makes teaching and learning more enjoyable.

Figure 1: The learning relationship is a contract between the individual and one's own private, professional, social roles in the interaction between the inner context-Person and the outer context-

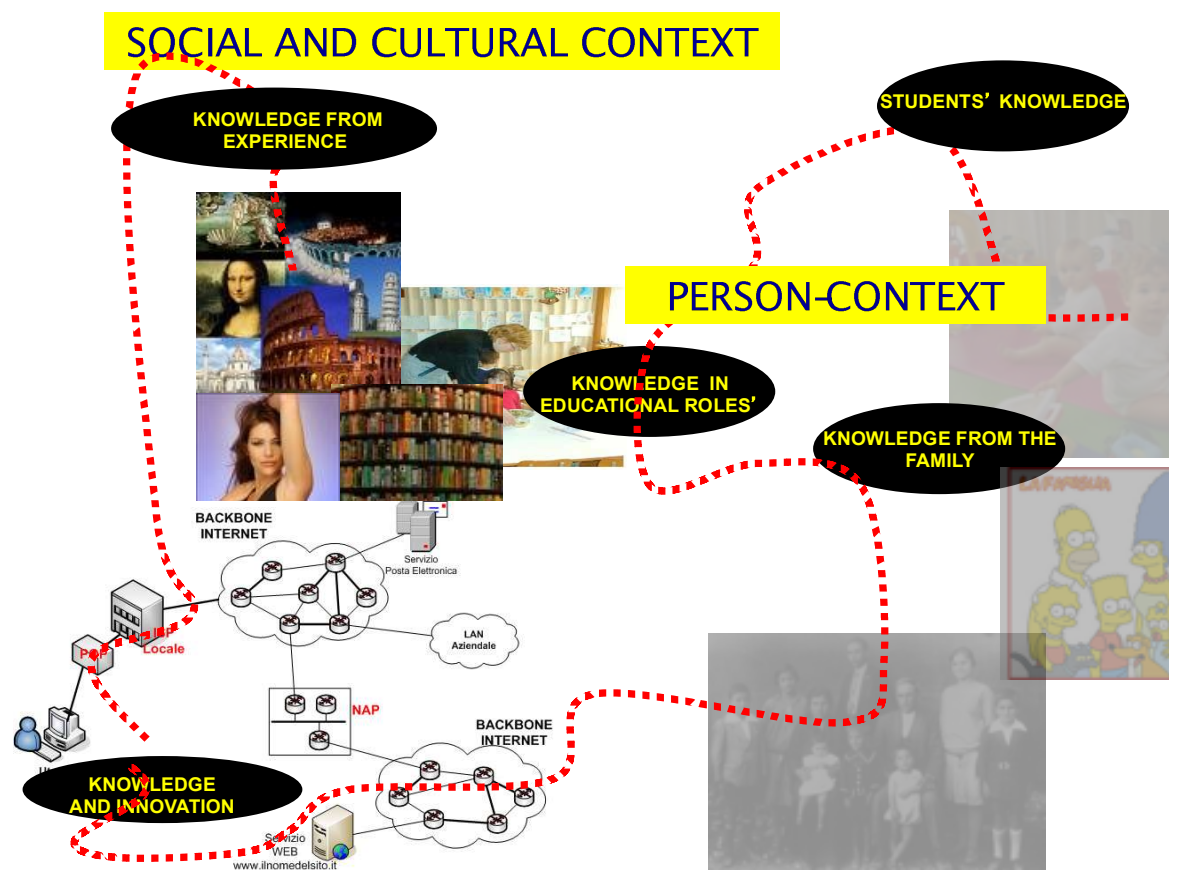

$2^{\text {nd }}$ EATA TA Research Conference 2012: Proceedings published as 
In Figure 2, large scale contents of TA training are integrated with teaching and learning processes, which are being developed in the field of training for educational and training roles.

TA in the Educational Field is not intended by the philosophy underpinning our research as a surrogate of other fields - if it has ever been intended like that. On the contrary, it is a repertoire of competences which enables us to affect learning and therefore didactics (Emmerton \& Newton 2004; Tudor, 2010)

TA tools act on different levels. Providing the students with such tools already in their basic training enhances the training of personalities who are less likely to experience non health.

Mastering relational instruments to explore and experiment one's own capacities, competences to learn and the possibility to potentiate them in time means to create store-houses for the future in which the seeds of know how to become are planted. As far as this issue is concerned, we ask ourselves some questions:

- Does all this provide future teachers with materials that facilitate the creation of tools and behavioural models consistent with the needs of the current world?

- To what extent, in this "equipment", is the culture of remedy disconnected from the culture of wellbeing?

- How do Self-efficacy characteristics, as intended by Bandura, and the characteristics of Autonomy, as intended by Berne, integrate in a perspective of close-knitted system that is oriented on the one hand to continuous improvement and on the other to the awareness of OKness within a frame of reference of social sustainability of ecology of development (Brofenbrenner 1979).

Figure 2: large scale contents of TA training integrated with teaching and learning processes, which are being developed in the field of training for educational and training roles.

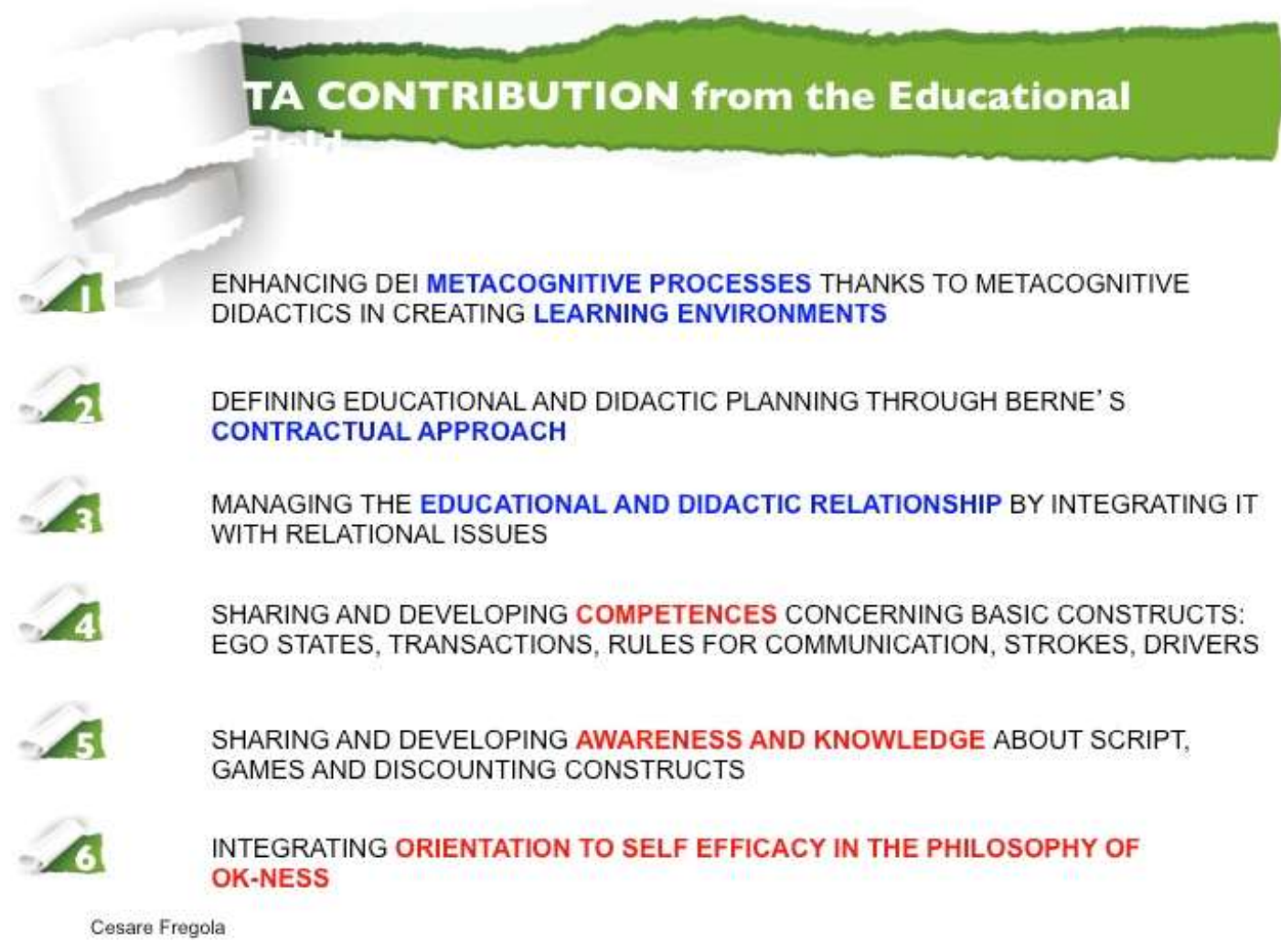




\section{A case: Getting on with - TA in educational contexts.}

\section{(C) 2012 Adele lozzelli}

We have seen how TA provides us with powerful tools that help us make the class a student-friendly environment. This is a reflection about working in a multicultural context, where we, as teachers, must be very careful and considerate in dealing with foreign students.

First of all, not only as teachers, but as TA educators, we hold ethical responsibility to be respectful of different cultures. The Ethics Manual of EATA reminds us that we must "behave in a respectful way towards self and others, including awareness of and sensitivity to different frames of reference, cultures and social norms".

Another important contribution from TA is the philosophy of OKness, which becomes a very precious tool in creating an ethical and enriching relationship with our students. In this paper, I describe a personal experience where an analysis of Existential Positions and Ego-States proved very important in the relationship with one of my students.

An educational relationship based on the principle of OKness has precious implications. Not only does it represent an ethical attitude towards the students, it also contributes to creating well-being in the teachers. It often frees us teachers from a sensation of impotence and distress, and it enhances empowerment both in teachers and students.

\section{A class of eighteen students, third year of Secondary School}

Several weeks after the beginning of school, A., a student from Albania, suddenly refused to read aloud in front of the class. I had the chance to reflect on different reactions on behalf of two colleagues of mine and analyse them from a perspective of OKness:

Italian teacher: I don't know why you won't read, but I don't care. Either you read aloud, or I will write it down in my register, and give you a very low grade at the end of the term.

I'm Ok - you're not Ok: I get rid of

French teacher: (speaking to a colleague in the teachers' room): It's too difficult with foreign students, I can't cope, I really don't know what to do, there's nothing to do!

I'm not Ok - you're not Ok: Get nowhere with

I tried to establish an Ok-Ok approach:

A., I have noticed that something is wrong. When I ask you to read aloud, you refuse to do it. If you explain me what the problem is, we can try and find a solution. Your participation is important, both for you, as you learn better, and for the rest of the group.

He replied: D. and M. make fun of me when I speak. They come from a different place in Albania, and they say that my accent is like a girl's. It's important for me to be considered a man. In my country, if you're not a man, you're worth nothing.

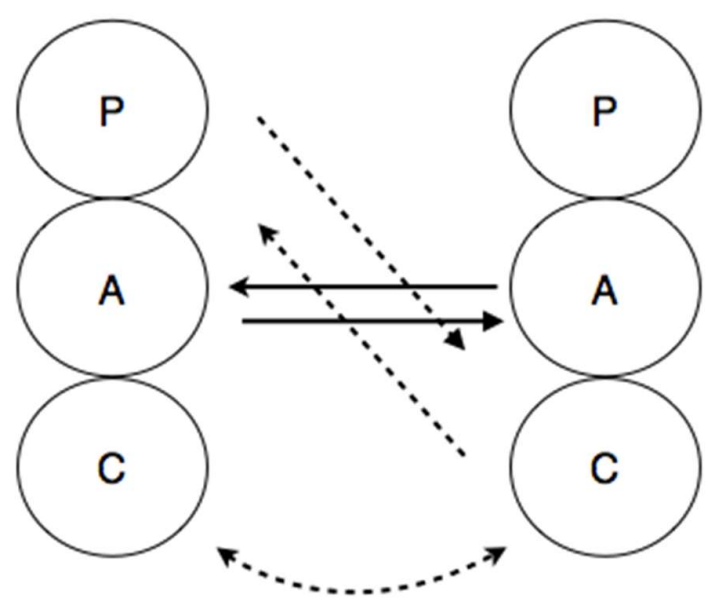

From a point of view of Ego-State analysis, the transaction can be thus diagrammed.

On the social level, the interaction is Adult - Adult, but on the psychological level it is Positive Nurturing Parent - Positive Adapted Child:

NP: "I care about you and what is troubling you. I want to take care of you"

AC: "Reassure me and help me, because I have a problem" 
The OK-OK attitude enabled me to show my concern for the student and his problem. Besides, he could feel that I considered him perfectly able to identify and describe the problem, which made him feel involved in the process of finding a solution together. On the one hand, he didn't feel he was being left alone and he was offered sincere and empathic support and acceptance. On the other hand, he didn't find a rescuer who offered him a solution, and this protected both of us from games.

OKness with foreign students implies going beyond the tolerant attitude that often characterises the teacherstudent relationship. It implies authentically and empathically conferring them dignity as an element of richness as well as complexity in our class. This case shows how the contribution of TA elements - in this case, analysis of Ego-States and principle of OKness - in educational contexts enhances authenticity, thus giving a chance to students and teachers to experience wellbeing and personal growth in a perspective of empowerment.

A further development of the application of TA in educational contexts is a new definition of "multicultural". Earlier, Cesare mentioned a study about the issue of the Cultural Parent, and we have heard that by observing the relevance of different cultural frames

\section{Questionnaire}

1) I often feel I am a bad son/daughter for my parents

2) It's easy for me to interact with my schoolmates

3) I am a good student

4) If I play a football match with my team, and the match isn't good, it's everyone's responsibility

5) It's important for me to have good marks in school

6) When I come back home, I always tell my parents what I've done at school and I talk to them for a while

7) Every time I have to face a new year at school, my parents reassure me about what will happen

8) When I play with my schoolmates, I'm often aggressive

9) My parents are affectionate

10) I love travelling: when I'm on holiday I leave with my parents and I discover new places

11) I often make my teachers angry

12) I feel at ease with my parents, and I always tell them what I think

13) I spontaneously express my opinions

14) People often envy us children because they say we have a lot of free time. Actually, I spend a lot of time at school or doing my homework

15) My parents don't care about what I do at school

16) When we discuss something in class, I speak as little as possible, and if they ask for my opinion, I stick to what the others say

17) In group discussions, I am very strict, so I can't find justifications

18) My parents are strict and demanding

19) I like having fun with my friends, especially when we're on holiday

20) I am on first name terms with my teachers, but sometimes I'm a little embarrassed when I have to greet them
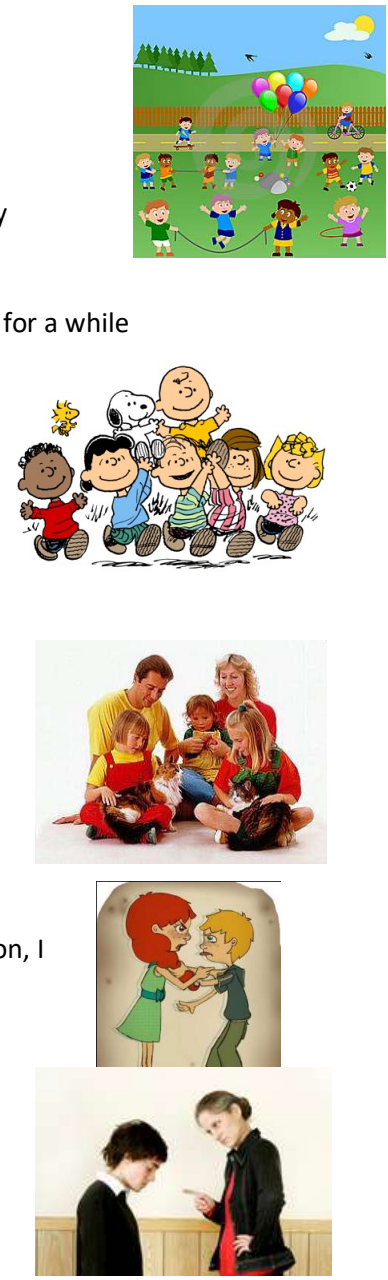
21) I'm vindictive during group discussions

22) I do not always agree with my schoolmates, even though I think it's important to be supportive

23) I have a group of friends. I often see them and I tell them about what I do in school and with my parents.

24) When I have to tell someone a secret, I carefully choose who to tell it to; most of the times, I speak to my best friend, but sometimes I make exceptions.

25) I don't study very hard for oral or written tests, because I know that my teachers will give me the same mark every time.

26) What I really don't like about school is that I'm being judged all the time by my teachers for assessment.

27) I am a diligent student, and I carefully carry out the tasks I am given

28) It's easy for me to cooperate with my schoolmates; I'm happy to do it

29) My parents care about what I do and help me do my homework

30) When my friends invent a new dance routine, and I have to judge their performance, I give each of them the mark they deserve

31) I often speak ill of my schoolmates.

32) I am a naughty student.

33) When we have to vote about something in class, e.g. to choose an activity, I prefer not to vote, so I won't do wrong to anyone.

34) I'm having a happy and free childhood

35) My study method is good

36) The relationship with my teachers is based on trust. This way, we can work very well.

37) I consider my teachers a bit like my parents. I'm very fond of them

38) When a schoolmate asks me a favour, I can't say no

39) When I organise a football match with my friends and I pretend I am their trainer, I observe their progresses and their behaviour in order to evaluate their actions

40) If I play football in the courtyard, I', the leader of actions in the game because I must win

41) I'm spontaneous with my teachers, and that's ok

42) If I get bored in class during the lesson, I don't listen to what the teacher says and I start drawing

43) If I go to the stadium to watch my favourite team, I shout and sing out loud to encourage the players to do their best in the match.

44) I'm not on friendly terms with my teachers

45) If I organise a dance competition with my friends, I never give them marks lower than $C$

46) I keep silent during lessons

47) I do everything it takes to be liked by my teachers

48) My goals at school are: listen carefully to the lessons, do well in my tests and keep up with the programme

49) When my teacher asks me to go up to the desk, I always wonder what I've done

50) I am too sincere, and this sometimes causes me troubles

51) I don't like going to school, and I can't wait for holidays

52) The only thing I do with my schoolmates is studying

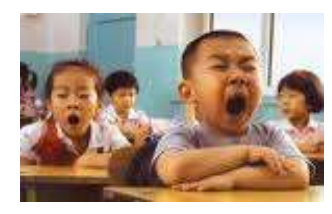

53) At school it's important for me not to be behind my schoolmates

54) I don't see my teachers outside school

55) Giovanni can't play, so I always take his place. This way, he can rest and our schoolmates don't make fun of him

56) I have a lot of toys: I play with what I want, and school is no longer my priority
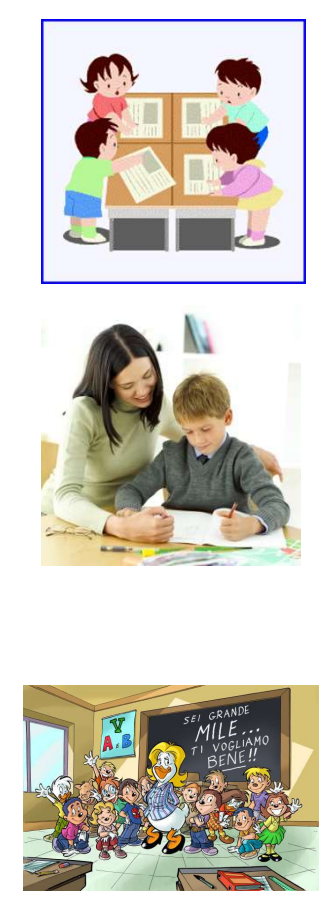
57) When I judge one of my schoolmates, I explain to them why I think those things about him or her

58) If some of my schoolmates can't do some activities, I give them advice so they can improve

59) I'm happy to speak ill of the Headmaster

60) I have my own frame of mind, and I apply it to every situation

61) I do what my teachers ask me to do, I don't work really hard

62) I don't poke my nose into my schoolmates' business

63) I really like doing my homework

64) I don't disturb during the lesson, or I won't understand what our teacher explains to us.

65) I defend our rights as students

66) I like sharing my experiences with my teachers

67) When we play a parlour game, and one of my schoolmates loses, I always suggest that he or she should pay the forfeit

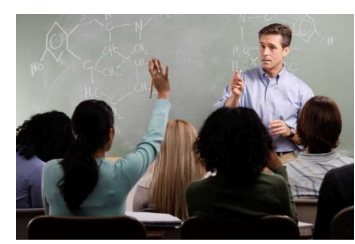

69) I come to an agreement with my schoolmates, so we can take turns to play

70) I can't tell my schoolmates what I really think of them

71) During the break, I would like to suggest new funny games, but I know it wouldn't work, as my schoolmates always play the same games

72) During the lesson, I sometimes speak in a low voice with my schoolmates

73) When we train for football in the courtyard, I let my schoolmates play freely, as long as they are ready for Sunday's match

74) It takes me a long time to prepare the games to play with my schoolmates

75) I become shy before my teachers

76) I do everything I can to help my teacher during the lesson, for example I hand out the photocopies

77) When I organise parlour games, I give penalties to those who don't respect the game rules.

78) When I have to explain the rules of a game, I try to be clear and speak slowly, so that every participant can understand

79) I play along with my schoolmates about the rules on taking turn in games

80) My life is well-balanced between family, school and hobbies

81) I'm good at school; I work really hard

82) I express my opinions clearly during group discussions

83) During the holidays I use my free time to improve myself in some subjects and study some topics in-depth

84) I can meet all of my schoolmates; I have no problems with them, and none of them is my favourite

85) If one of my schoolmates talks openly about a problem, I don't feel vindictive, I try to suggest solutions

86) I am diligent in doing my homework; my work is neat and tidy

87) I am free to be myself with my schoolmates, I show my qualities and my defects

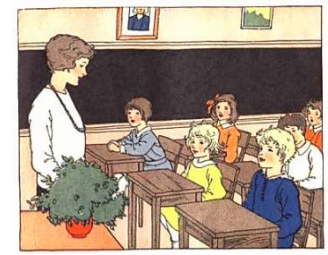

88) I can't stand it when my teachers criticise me, and sometimes I answer back

89) School rules must be respected

90) I go along well with my teachers, I have no problems with them 


\section{Constructing the Egogram Chart : The three phases:}

1. Administering a questionnaire made up of 90 true/false questions. Questions are about how children interact, in certain circumstances, both with adults and peers. It is important that children's answers are as "immediate" as possible.

2. Tabulation of the answers in a grid. (Chart 1)

The grid is made up by 9 columns which comprise the sub-categories of Ego States. In this grid, the corresponding items have been placed in the column with the related Ego State. In order to calculate the points, "quite false" answers must not be considered. One point is assigned to any "quite true" answer, in the columns where the number of the corresponding item is indicated.

Then, the number of points in each column must to be added up.

3. Graphical realisation of the egogram: (Chart 2) After the score has been calculated, according to the grid, the results are transferred into an empty egogram, marking as many boxes as the points made corresponding to each Ego-State column. On this chart, the points for answers are on the $y$-axis and the Ego-States on the $x$-axis. The histogram we obtain for each State gives us the energy involved and the energetic difference between states. It also describes the dominant States (Dusay, J. M., Egograms and the "Constancy Hypothesis". TAJ, 2(3), 37-41.1972).
The chart provides a profile for each child; there is no judgement about the person, only the likeliest aspect of his/her transactions with others. Each Ego-State, in this chart, can have both a functional and a dysfunctional aspect.

\section{"Persecutor" Parent}

A person who sets unreasonable limits or applies the existing limits with aggressiveness and without protection

\section{"Rescuer" Parent}

A person who inopportunely offers his/her help, asks for something in return and limits the other's selfexpression

\section{"Controlling" Parent}

Positive aspect: A person who takes a stand, guides, reminds rules and values to others; he or she can express his/her opinions in a clear, straightforward and timely way.

Negative aspect: A person who scolds, punishes, criticises and dictates

"Nurturing" Parent

Positive aspect: a person who takes care of himself/herself and others, reassures and advises, gives support.

Negative aspect: a person who has an over-protective attitude, worries excessively about the others.

Chart 1: Tabulation of answers

\begin{tabular}{|c|c|c|c|c|c|c|c|c|}
\hline $\begin{array}{l}\text { Persecutor } \\
\text { Parent }\end{array}$ & $\begin{array}{l}\text { Rescuer } \\
\text { Parent }\end{array}$ & $\begin{array}{l}\text { Controlling } \\
\text { Parent }\end{array}$ & $\begin{array}{l}\text { Nurturing } \\
\text { Parent }\end{array}$ & ADULT & Free Child & $\begin{array}{l}\text { Adapted } \\
\text { Child }\end{array}$ & $\begin{array}{l}\text { Rebellious } \\
\text { Child }\end{array}$ & $\begin{array}{l}\text { Over-adapted } \\
\text { Child }\end{array}$ \\
\hline 4 & 7 & 5 & 6 & 2 & 12 & 3 & 8 & 1 \\
\hline 10 & 20 & 17 & 9 & 15 & 13 & 16 & 11 & 14 \\
\hline 18 & 29 & 27 & 19 & 23 & 24 & 22 & 25 & 26 \\
\hline 21 & 38 & 30 & 28 & 35 & 34 & 36 & 32 & 33 \\
\hline 31 & 43 & 44 & 37 & 39 & 41 & 47 & 42 & 40 \\
\hline 46 & 55 & 53 & 57 & 48 & 63 & 61 & 45 & 49 \\
\hline 54 & 56 & 58 & 66 & 52 & 72 & 70 & 50 & 62 \\
\hline 59 & 65 & 68 & 74 & 60 & 82 & 79 & 51 & 71 \\
\hline 67 & 73 & 83 & 78 & 69 & 87 & 84 & 64 & 75 \\
\hline 77 & 76 & 89 & 85 & 80 & 90 & 86 & 88 & 81 \\
\hline$/ 10$ & $/ 10$ & $/ 10$ & $/ 10$ & $/ 10$ & $/ 10$ & $/ 10$ & $/ 10$ & \\
\hline \multicolumn{5}{|c|}{ Total Parent (divided by 4) } & \multicolumn{4}{|c|}{ Total Child (divided by 4) } \\
\hline
\end{tabular}




\begin{tabular}{|c|c|c|c|c|c|c|c|c|c|}
\hline \multirow[b]{2}{*}{10} & \multicolumn{3}{|c|}{ Aspetto disfunzionale } & \multicolumn{3}{|c|}{ Aspetto funzionale } & \multicolumn{3}{|c|}{ Aspetto disfunzionale } \\
\hline & & & & & & & & & \\
\hline 9 & & & & & & & & & \\
\hline 8 & & & & & & & & & \\
\hline 7 & & & & & & & & & \\
\hline 6 & & & & & & & & & \\
\hline 5 & & & & & & & & & \\
\hline 4 & & & & & & & & & \\
\hline 3 & & & & & & & & & \\
\hline 2 & & & & & & & & & \\
\hline 1 & & & & & & & & & \\
\hline 0 & $\begin{array}{l}\text { Persecutor } \\
\text { (-) }\end{array}$ & $\begin{array}{l}\text { Rescuer } \\
\text { (-) }\end{array}$ & $\begin{array}{l}\text { Controlling } \\
(+)\end{array}$ & $\begin{array}{l}\text { Nurturing } \\
(+)\end{array}$ & $(+)$ & $\begin{array}{l}\text { Free } \\
(+)\end{array}$ & $\begin{array}{l}\text { Adapted } \\
(+)\end{array}$ & $\begin{array}{l}\text { Rebellious } \\
\text { (-) }\end{array}$ & $\begin{array}{l}\text { Over } \\
\text { adapted } \\
(-)\end{array}$ \\
\hline & PARENT & & & ADULT & & & CHILD & & \\
\hline
\end{tabular}

\section{Francesca's comment about the results}

The picture we obtain from the analysis of this chart is the following:

Dysfunctional aspects:

- The Persecuting Parent increased: in some cases was too strict because I wanted them to respect the rules

- The Rescuing Parent Ego state wasn't affected

- The Rebellious Child Ego State decreased: the child demonstrated greater initiative and, as shown by the increase in the Controlling Parent, he seems to have developed a greater acceptance of rules. This also led to a decrease in the Over-Adapted Child, and a subsequent increase in the positive Adapted Child.
Functional aspects:

- Nurturing Parent remained constant

- The Adult Ego State increased: I assigned the Child tasks which carried greater responsibility, and, through the activity proposed in the fourth unit, the child developed a greater relational competence and awareness of the consequences of his behaviour

- The Free Child Ego State increased: I encouraged the student to express freely during collective discussions, and this fostered him to speak without shame; this latter aspect actually reached the highest level. 


\section{First steps for a bibliography integrated for research purposes in AT and the relation of learning}

Alberici, A., (1999), Imparare sempre nella società della conoscitiva. Dall'educazione degli adulti all'apprendimento durante il corso della vita. Torino, Paravia.

Amenta, G., (1999), Il counselling in educazione, Brescia, La Scuola.

Ashman, A., Conway R.(1991), Guida alla Didattica Metacognitiva. Trento, Edizioni Erickson,

Ausubel, D.P., (1991), Educazione e processi cognitivi, Milano, Franco Angeli.

Ballanti G., (1979), Analisi e modificazione del comportamento insegnante, Teramo, Giunti \& Lisciani.

Ballanti, G., (1988), Modelli di apprendimento e schemi di insegnamento, Teramo, Giunti \& Lisciani.

Ballanti, G., Fontana L., (1981), Discorso e azione nella pedagogia scientifica, Teramo, Giunti \& Lisciani.

Bandura, A., (2000), Autoefficacia: teoria e applicazioni, Trento, Erickson.

Bandura, A. (1997), Self-efficacy: The exercise of control, New York, Freeman.

Bandura, A. (1993), Perceived self-efficacy in cognitive development and functioning. Educational Psychologist. n.28.

Bandura, A. (1986), Social foundations of thought and actions: a social cognitive theory. Englewood Cliffs, NJ: Prentice Hall.

Barnes, G. (2007) "Not without the couch: Eric Berne on basic differences between transactional analysis and psychoanalysis. "Transactional Analysis Journal, 37,1, pp 41 - 50

Barrow, G. "Taching, Learning, schooling, and script ", TAJ vol 39, number 4, p. 298

Bateson, G., (1972), Verso un'ecologia della mente, Adelphi.

Berne E., (1992), Intuizione e Stati dell'Io, Astrolabio, Roma.

Berne, E. (1961) Transactional analysis in psychotherapy: a systematic individual and social psychiatry. New York: Grove Press (tr. it. Analisi transazionale e psicoterapia. Astrolabio: Roma, 1971)

Berne, E. (1962) "In treatment" Transactional Analysis Bulletin, $1(2), 10$

Berne, E. (1966) Principles of group treatment. New York: Grove Press (tr.it. Principi di terapia di gruppo. Astrolabio: Roma, 1986)

Block, H., (a cura di), (1972), Mastery learning, Torino, Loescher.

Bloom, B.S. (1979), Caratteristiche umane e apprendimento scolastico, Armando, Roma.

Bloom, B.S., (1972), Conseguenze affettive del profitto scolastico, in Block J.K., (a cura di), in Mastery Learning, Torino, Loescher.

Bloom, B.S., (1983), Tassonomia degli obiettivi educativi,La classificazione delle mete dell'educazione, Vol 1: Area cognitiva, Teramo, Giunti \& Lisciani.

Bloom, B.S., Krathwoohl D.R., Masia B.B., (1984-

1985),Tassonomia degli obiettivi educativi, La classificazione delle mete dell'educazione, Vol 2 Area affettiva.,Teramo, Giunti $\&$ Lisciani.
Boscolo, P., (1997), Psicologia dell'apprendimento scolastico. Aspetti cognitivi e motivazionali, Torino, UTET.

Bocci, F., (2012), Una mirabile avventura, storia dell'educazione dei disabili da Jean Itard a Giovanni Bollea, Firenze, Le Lettere.

Brofenbrenner, U., (1979), Ecologia dello sviluppo umano, Bologna, II Mulino.

Brook, K .A. (1996) A Fresh Look at Permission Transactional Analysis Journal 26 (2) April 160-166

Bruner, J.S., (1971), Prime fasi dello sviluppo cognitivo, Roma, Armando.

Chalvin, M.J. (1986), AT ed insegnamento scolastico. Roma, San Paolo, 1986.

Clarkson, P. (1992) Transactional analysis psychotherapy. An integrative approach. London and New York, Tavistock/ Routledge

Codice Etico dell'EATA , (2006), Ultima revisione dopo la riunione del Consiglio, Santiago de Compostela.

Colasanti A., Mastromarino R., (1991), Ascolto Attivo, Roma, IFREP.

Cornell, W. F. (1996) "Setting the therapeutic stage: the initial sessions". Transactional Analysis Journal, 16,1,pp 4-10

Cornoldi, C., (1995), Metacognizione e Apprendimento. Bologna, II Mulino.

Crossman, P. (1966), Permission and Protection Transactional Analysis Bulletin 5(19) 153-154

De Landsheere , G., (1983), Introduzione alla ricerca in educazione, Firenze, La Nuova Italia, 1983.

De Landsheere, G., (1973), Introduzione alla ricerca in educazione, Firenze, La Nuova Italia.

De Landsheere, G., De Landsheere, V., (1977), Definire gli obiettivi dell'educazione, Firenze, La Nuova Italia.

De Martino, M., Novellino, M., Vicinanza, A., (1990), L'alleanza nella relazione didattica. Napoli, Liguori.

De Martino, M., Novellino, M., Vicinanza, A., (1990), L'alleanza nella relazione didattica. Napoli, Liguori.

De Vecchi G., (1998), Aiutare ad Apprendere. Firenze, La Nuova Italia,

De Vecchi, G., Carmona-Magnaldi N., (1999), Aiutare a Costruire le Conoscenze. Firenze, La Nuova Italia.

Delors, J., (1997), Nell'educazione un tesoro. Rapporto UNESCO della commissione internazionale sull'Educazione per il Ventunesimo secolo, Roma, Armando.

Drego P, (1983), The culture Parent, TAJ, 13,224-227, Berne E., The Structure and Dynamics of

Drego, P. (1996). Cultural Parent: oppression and regeneration Transactional Analysis Journal, 26, 58-77.

Dusay, J. M., (1972), Egograms and the "Costancy Hypothesis". TAJ, 2(3), 37-41.

Emmerton, N. and Newton T., Il viaggio dell'Analisi Transazionale educativa dai suoi inizi ad oggi, TAJ, vol 34, number 3, july 2004 (pp: 283-289). Keit Tudor Lezione magistrale Performat, 2010 
Emmerton, N., and Newton, T., Il viaggio dell'Analisi Transazionale educativa dai suoi inizi ad oggi, TAJ, vol 34, number 3, july 2004 (pp: 283-289).

English, F.(1996), The Three-cornered Contract. TAJ. 5, 383-384. 1975. Anche in AA.VV., TA in Organizations, $1^{\circ}$ vol. of Selected Articles 1974-1994, ITAA, Ed. Van Poelje S. \& Steinert T.

Erikson, E.H. (1999), I cicli della vita. Continuità e mutamenti, Roma, Armando.

Erskine. R. G. (1973) "Six stages of treatment" Transactional Analysis Journal, 3, 3, pp 17-18

Favorini, A.M., (2004), Il contratto nella formazione e nell'apprendimento. Esperienze educative e didattiche con I'Analisi Transazionale, Milano, Franco Angeli.

Ferri P., Nativi digitali, Bruno Mondadori, Milano 2011

Franta, H. (1985), Relazioni sociali nella scuola. Promozione di un clima positivo,

Fregola C., (2011), Analisi Transazionale e processi educativi. Esplorazioni per curiosare nel Campo Educativo nella complessità sociale e culturale del nostro tempo, in Tangolo $\mathrm{E}$. Vinella P. (A cura di), Professione Counsellor, Competenze e prospettiva nel counselling analitico transazionale, Pisa, Felice Editore.

Fregola C., (2007), I modelli di intervento dal micro al macro contesto, in: C. Migani, V. Vivoli, (a cura di), Promuovere il benessere nelle scuole: esperienze e prassi a confronto, Roma, Carocci.

Fregola C., Piu A., (2011), Simulandia. Giochi di simulazione e ambienti di apprendimento della matematica, Giornale Italiano della Ricerca Educativa • IV • 6 / GIUGNO

Fregola C., Piu A., (Eds) (2010), Simulation and Gaming for Mathematical Education: Epistemology and Teaching Strategies, IGI Global,Hershey (PA).

Fregola, C. and Olmetti Peja, D. (2007), Superare un esame. Come trasformare ansia emotività e studio in risorse strategiche. Napoli, Edises.

Freire, P. (1970), Pedagogy of the oppressed, London, Penguin.

Gagnè, E., (1989), Psicologia Cognitiva e Apprendimento Scolastico, Torino, SEI

Gagnè, R. M. (1973), Le condizioni dell'apprendimento, Roma, Armando.

Gagnè, R.M., Briggs J.M., (1990), Fondamenti di progettazione didattica, Torino, SEI

Gardner H.,(1995), L'educazione delle intelligenze multiple: dalla teoria alla prassi

Gardner, H. (1989), Formae Mentis. Saggio sulla Pluralità dell'Intelligenza. Milano, Feltrinelli.

Gardner, H. (1993), Educare al comprendere, Milano, Feltrinelli, 1993.

Gibson D.L. The classic non-contract, TAJ, Vol $4^{\circ} n^{\circ} 2$, p. 31.

Grant Jan, "How the philosophical assumption of TA complement the theory of adult education" TAJ, 34, p-272

Handy C. (1994), L'epoca del paradosso. Dare un senso al futuro, Milano, Olivares.

Hargaden, H. and Sills, C. (2002) Transactional analysis a relational perspective. Hove: Brunner - Routledge

Hill W.F. (2000), L'apprendimento. Interpretazioni psicologiche, Bologna, Zanichelli.
James, M. (1977) Techniques in transactional analysis for psychotherapists and counselors. Reading, Addison Wesley

James, M., Jongeward, D., (1985), Nati per vincere. Roma, San Paolo.

Jenkis H., Culture partecipative e competenze digitali. Media education per il XXI secolo, Guerini Associati, Milano 2010

Kahler, T. (1975), Drivers: the Key to the Process of Scripts Transactional Analysis Journal 5 (3)

Kahler, T. (1997). The miniscript, In: Barnes, G. (a cura di) (1977). Transactional Analysis after Eric Berne. New York: Harper's College. (Tr. it. Analisi transazionale: un punto di vista integrativo in Scilligo, P. (a cura di) (1983), Gestalt e Analisi Transazionale, Vol. II. Roma, LAS.

Laeng, M., (1984), L'educazione nella civiltà tecnologica, Roma, Armando.

Laeng, M., (2001), Unità della cultura e costruzione di concetti scientifici, Lecce, Pensa.

Lèvy, P., (1997), Il virtuale, Milano, Raffaello Cortina.

Lewis, H. (1990), A question of values. San Francisco, Harper \& Row.

Lovell, K., Lawson K.S., (1972), La ricerca nel campo educativo, Firenze, Giunti Barbera.

Lovell, K., Lawson, K.S., La ricerca nel campo educativo, Firenze, Giunti Barbera, 1972.

Mager R.F., (1978), Come sviluppare l'atteggiamento ad apprendere, Teramo, Giunti \& Lisciani.

Mager R.F.(1972), Gli obiettivi didattici, Teramo, E.I.T..

Mager, R.F., Beach K.M.Jr. (1967), Come progettare

I'insegnamento, Teramo, Giunti \& Lisciani.

Mastromarino, R., Scoliere, M., (1999), Introduzione all'analisi transazionale. II modello 101, Roma, IFREP.

Maturana, H. e Varela, F. (1992), L'albero della conoscenza, Milano, Garzanti.

Maturana, H. e Varela, F. (1992), Macchine ed esseri viventi. L'autopoiesi e l'organizzazione.

McLuhan M., (2004), Understanding Media: The Extension of Man, Routledge.

Messana, C., (1999), Valutazione formativa e personalità. Prospettive di sviluppo della motivazione scolastica e della stima di sé, Roma, Carocci.

Mezirow, J. (2000), Learning as Transformation.Critical Perspectives on a Theory in Progress San Francisco, JosseyBass.

Miglionico, A., (2000), Sistema di Riferimento, spazio personale e rapporto copionale. Atti del Convegno Nazionale SIAT 98, Torino, 1998.

Miglionico A., Manuale di Comunicazione e Counselling, CSE, Torino,

Miglionico, A. e Vinella, P., (2000), I Contratti in psicoterapia e counselling, in Miglionico A. et Al. Manuale di comunicazione e counselling, Torino, CSE,

Moiso, C., \& Novellino M., (1982), Stati dell'lo, Roma, Astrolabio

Montuschi, F., (1994), Il contratto nei campi educativi, in "Rivista italiana di Analisi Transazionale", XIV,26-27.

Montuschi, F., (1997), Fare e Essere, Assisi, Cittadella Editrice. 
Montuschi, F., (1993), Competenza affettiva e apprendimento, Brescia, La Scuola.

Montuschi, F., (1987), Vita affettiva e percorsi dell'intelligenza, Brescia, La Scuola.

Montuschi, (1985), F., Copioni degli insegnanti, stati dell'lo e opzioni educative. Riv. di aT. 5, 8-9, Roma, Simpat.

Montuschi, F., (1984), Teacher's Scripts and In-Service Training Programs. TAJ. 14, 1.

Morin, E. (2001), La natura della natura, Raffaello Cortina,.

Napper R (2010) The Individual in Context in Erskine R ed Lifescripts pub Karnac London

Napper, R., (2011), II Genio di Berne e l'ampiezza della portata dell'AT: Esplorazione del quadro culturale e del contesto del setting, IAT News, Roma.

Napper, R., \& Newton, T. (2000), TACTICS: TA concepts for all trainers, teachers and tutors and insight into collaborative learning Ipswich, United Kingdom, TA Resources.

Neisser, U.,(1981), Conoscenza e realtà, Bologna, II Mulino.

Newton T., and Napper R., La visione d'insieme: la supervisione come quadro di riferimento per tutti i campi

Newton, T. (2003)., Identifyng educational philosophy an practice through imagoes in TA training groups TAJ 33, 4, 321 331.

Noriega G (2010) Transgenerational Scripting in Erskine R ed Lifescripts pub Karnac Schmid, B. (1992). Transactional analysis and social roles. In: Mohr, G., \& Steinert, T. (Eds) Growth and Change for Organisations. Berkeley, CA: ITAA, 2006. Schmid, B. (1992). Transactional analysis and social roles. In: Mohr, G., \& Steinert, T. (Eds) Growth and Change for Organisations. Berkeley, CA: ITAA, 2006. Also http://www.systemischeprofessionalitaet.de/isbweb/ content/view/30/78/

Novak, J.D., Gowin D.B., (1989), Imparando a imparare, Torino, SEl.

Novellino, M. (2003), La sindrome dell'uomo mascherato, Milano, Franco Angeli.
Olmetti Peja D.(1998). Teorie e tecniche dell'osservazione in classe, Firenze, Giunti.

Postic, M., De Ketele J.M., (1993), Osservare le situazioni educative. I metodi osservativi nella ricerca e nella valutazione, Torino, SEI.

Prensky M., From Digital Natives to Digital Wisdom: Hopeful Essays for 21st Century Learning, Corwin Press, Thousand Oaks (CA) 2012

Prensky M., Mamma Non Rompere. Sto Imparando!, MPlayer Edizioni, Milano 2009

Prensky M., Teaching Digital Natives: Partnering for Real Learning, Corwin Press, Thousand Oaks (CA) 2010

Romanini, M. T., (1999),Costruirsi Persona, Milano, La Vita Felice Edizioni.

Scilligo, P., Bianchini, S., A.T., (1990), I Premi Eric Berne, Roma, IFREP.

Sternberg, R.J., (1998), Stili di Pensiero. Trento, Erickson.

Tudor, K. ( 2002) Transactional analysis approaches to brief therapy. London: Sage Publications

Tudor. K. (2003) The neopsyche: The integrating adult ego state. In C. Sills \& H. Hargaden (Eds.), Ego states (Vol 1 of key concepts in transactional analysis: Contemporary views) (pp. 201-231). London, Worth Publishing.

Tudor Keit Lezione magistrale audio, Pisa, Performat, 2010

Tuffanelli, L. (a cura di). (1999). Intelligenze, Emozioni e Apprendimenti. Trento, Erickson.

Vertecchi, B., Decisione didattica e valutazione, Firenze, La Nuova Italia, 1993.

Von Bertalanffy, L. (1968), General System Theory. N.Y, George Brazillier Company.

Watzlawick P., Beavin J.H. e Jackson D.D., (1971) Pragmatica della comunicazione, Roma, Astrolabio.

Woollams, S., \& Brown. M. (1985), Analisi Transazionale, Assisi, La Cittadella. 